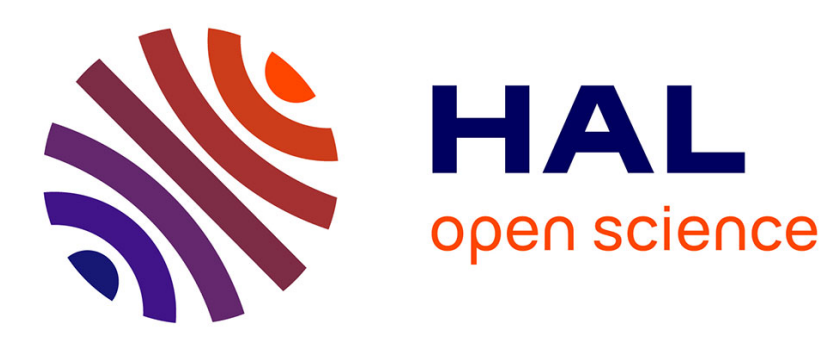

\title{
On Site Raman Analysis of the earliest known Meissen Porcelain and Stoneware
}

Philippe Colomban, Véronique Milande

\section{To cite this version:}

Philippe Colomban, Véronique Milande. On Site Raman Analysis of the earliest known Meissen Porcelain and Stoneware. Journal of Raman Spectroscopy, 2006, 37, pp.606-613. hal-00120393

\section{HAL Id: hal-00120393 \\ https://hal.science/hal-00120393}

Submitted on 14 Dec 2006

HAL is a multi-disciplinary open access archive for the deposit and dissemination of scientific research documents, whether they are published or not. The documents may come from teaching and research institutions in France or abroad, or from public or private research centers.
L'archive ouverte pluridisciplinaire HAL, est destinée au dépôt et à la diffusion de documents scientifiques de niveau recherche, publiés ou non, émanant des établissements d'enseignement et de recherche français ou étrangers, des laboratoires publics ou privés. 
On-site Raman analyses were performed at the Musée national de Céramique, Sèvres, France, on selected rare items of the earliest known European hard-paste porcelains and stonewares, produced from $\sim 1710$ to $\sim 1750$ in the Meissen workshop (Saxony) founded by J.F. Böttger and E.W. von Tschirnhaus. Comparison with measurements made at the laboratory makes it possible to differentiate between diverse pastes and colourless glazes, as well as the identification of various pigments including unexpected lapis lazuli.

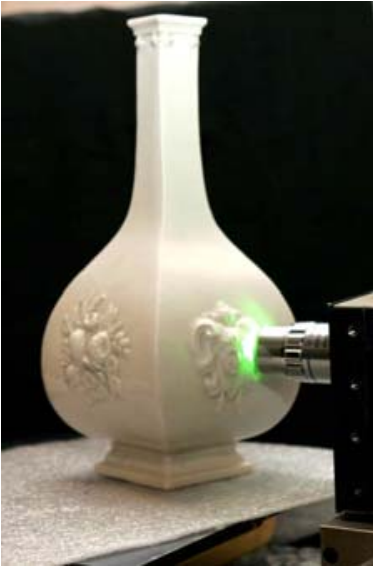

Ph. Colomban, and V. Milande

On Site Raman Analysis of the earliest known Meissen Porcelain and Stoneware 


\title{
On Site Raman Analysis of the earliest known Meissen Porcelain and Stoneware
}

\author{
Philippe Colomban $^{\mathrm{a}^{*}}$ and Véronique Milande ${ }^{\mathrm{b}}$ \\ a Laboratoire de Dynamique, Interactions et Réactivité (LADIR), UMR 7075 CNRS-Université Pierre et \\ Marie Curie, 2 rue Henry Dunant 94320 Thiais, France \\ busée national de Céramique, Place de la Manufacture, 92310, Sèvres, France
}

\begin{abstract}
On Site Raman analyses were performed at the Musée national de Céramique, Sèvres, France, on selected rare items of the earliest known European hard-paste porcelains and stonewares, produced from $\sim 1710$ to $\sim 1750$ in the Meissen workshop (Saxony) founded by J.F. Böttger and E.W. von Tschirnhaus. Characteristic on-site Raman signatures have been obtained for white Sake bottles from $\sim 1715$, a green bowl, depicting a purple landscape and dated $27^{\text {th }}$ August 1726, a middle of the $18^{\text {th }}$ century produced figurine and coffee cups. In addition some artefacts (a red polished stoneware cup from ca. 1710-1715, a white ewer stopper from 1725, a blue underglaze decorated flat stopper believed to have been manufactured after 1719, and decorated coffee cups) were analysed at the laboratory. Raman spectra identified different types of mullite-rich bodies, including calcium-rich and quartz-containing pastes. Different types of glazes and pigments (haematite, Naples yellow, cassiterite, lapis lazuli ...) have also been identified. The results are discussed in the light of previous chemical analyses and historical records. We propose characteristic parameters to discriminate between the different production technologies.
\end{abstract}

Keywords : glaze, glass, porcelain, stoneware, Meissen, Böttger, pigments, $18^{\text {th }}$ century.

* Corresponding author

fax 33149781118 colomban@glvt-cnrs.fr 


\section{INTRODUCTION}

Since the middle of the fifteenth century, porcelain in large quantities was imported from China, Vietnam and Japan to Europe. There are reports of Venetian efforts to reproduce Asian porcelain but no proof of production was established before the period 1575 to 1587 . However, during this short period of time about a hundred pieces of porcelain were produced under the patronage of the Grand Duke Francesco I de Medici at Florence, using a hybrid technology, which is an intermediate between fritware and hard-paste porcelain technologies, [1 and references herein]. At the end of the seventeenth century, each of these two technologies were established in Europe. In France the soft-paste porcelain kaolin-free route was followed at for instance the Saint-Cloud Factory [2,3] and in Saxony the hard-paste route was taken. The technology of French soft-paste porcelain was based on the use of a high lime content and the very plastic calcareous illitic clays of Argenteuil (see details in ref [4]), which has very specific Raman signatures [3,5] and made it possible to produce nice artefacts in the Chinese and Japanese style. Hellot (1685-1766), a leading scientist attached to the VincennesSèvres Factory, reported how a mixture of soda ash, sea salt, potassium nitrate, lime and albaster (or gypsum) were milled together and fired at $\sim 1100^{\circ} \mathrm{C}$ [4]. Count Ehrenfried Walther von Tschirnhaus (1651-1708), who on a visit to Paris in 1698, saw a "burning glass", carried out studies of Saxon mineral resources in collaboration with mining superintendant Pabst von Ohain and established glass factories with the capability to produce burning-lenses of more than a meter in diameter [4,6]. With these instruments he reached higher temperatures than had previously been attained in Europe. He reported melting pure lime and sand at a temperature of $1436^{\circ} \mathrm{C}$. Joachim Böttger (1682-1719), a Pabst assistant, established a laboratory to foster the production of porcelain in 1707 [4,7]. The production of a variety of products ranging from marbled bodies to artificial gems, to red and brown stonewares were attempted [7,8]. On March 28, 1709 Böttger announced to Augustus the Strong, Elector of Saxony and King of Poland his success in producing "red porcelain" using a mixture of red clay from Zwickau added to clay from Plauen and of "white porcelain" with white Colditz clay mixed with calcined albaster (calcium sulfate) from Nordhausen, but soon a white kaolin from Aue was being used [7,8]. After Böttger's death in 1719, reports say that the Meissen formula was modified and included, after $\sim 1733$, Siebenlehn feldspar as a flux in place of calcium [8]. Previous electron microscopy analyses showed that Böttger porcelains do not contain a large amount of the quartz phase common in Chinese (and most other European) hard-paste porcelains [4-6].

Previously we have analysed a sample made from the paste taken at the Meissen factory by Alexandre Brongniart (Director of the Sèvres Factory and Museum from 1800 to 1847, author of a famous book on porcelain technology published in 1844) and stored at the Sèvres factory in the middle of the nineteenth century (see Fig. 2 in ref [9]) and pointed out that the Raman signature consists of a nearly pure mullite spectrum. The compositional change from a calcium-based paste in the beginning of the Meissen production to a potassium-based flux after 1730 necessarily implied the formation of various intermediate phases in which the proportions of materials varied, offering a way to discriminate between the different technologies from their Raman signatures. We present here the results of a preliminary study to tentatively establish the characteristic signature of earliest produced Meissen artefacts. The high value of early Meissen production ware motivated us to make most of the measurements with a portable instrument at the Musée national de Céramique, Sèvres. Most of the studied samples have been exhibited at the Musée' exhibition "Porcelaine de Saxe” in 1952 [10] and entered very early in the Museum collection. 
We will attempt to answer the following questions: i) are Raman microscopy a technique able to discriminate between the different pastes and glazes produced, as we proceed in our study of soft-paste French productions? ii) Is this possible through on-site measurements or are additional measurements at the laboratory required? iii) We will determine the Raman signatures that could be useful in the future to discriminate between original productions and fakes, including those made during Böttger' times (e.g., at Plaue Factory, Brandebourg).

\section{EXPERIMENTAL}

\section{Samples}

The objects selected are presented on Plate 1 . They belong to the collection of the Musée national de Céramique, Sèvres (France) and most of them have been there exhibited at the 1952 "Porcelaine de Saxe" exhibition [10] and some of them entered in the collection at the time of the Museum foudation. Among the samples studied are a polished red stoneware tea cup (MNC308, entered in the collection in 1802) believed to date from 1710-1715, a white Sake bottle from a pair (MNC451 ${ }^{2}$ from 1715, entered in the collection in 1806, \#36 in catalogue [10]), a white ewer stopper (MNC 7152 from ca. 1725, M. Cornu gift, 1876) a broken flat stopper with a blue underglaze décor believed to have been produced after 1719 (MNCxxx), a green bowl with depicting a purple landscape dated $27^{\text {th }}$ August 1726 (MNC2274 ${ }^{9}$, entered in 1837, \#131 of [10]), a "celadon" coffee cup (MNC 14231, Marquis de Grollier Bequest, entered in 1908, \# 47 in [10]) and a polychrome figurine produced in the middle of the $18^{\text {th }}$ century (MNC 11056, Mme Dècle Bequest, 1902, \#503 in [10] ).

\section{Technique}

On-site micro-Raman measurements were performed using a portable HE532 system (Jobin Yvon Raman SAS, Longjumeau, France). The instrument is optimized to work with a $532 \mathrm{~nm}$ laser excitation and spectra were recorded in the range $160-3000 \mathrm{~cm}^{-1}$ with Olympus MSPLAN $^{\mathrm{TM}}$ Ultra Long Working distance objectives (x80 and x50, total magnification x800 and $\mathrm{x} 500$ ). A portable XYZ plate (weight $\sim 3 \mathrm{~kg}$ ) supports the SuperHead ${ }^{\mathrm{TM}}$ allowing micrometer scale displacements (see Plate 1a, b \& e) to select a "good" location for spectral recording (spot waist: $\sim 3-10 \mu \mathrm{m}$ ). In addition the object itself is put on a support, which can be moved in different directions. Typically, the power of illumination at the sample was 10-20 $\mathrm{mW}$. A filter drastically decreases the laser intensity and enables one to choose, visually the area to be analyzed and to optimize the laser focus. Control of the penetration depth was obtained by checking the Raman signal intensity on the computer. LabSpec ${ }^{\circledR}$ (Jobin-Yvon) software was used to control the HE system and the data acquisition.

A multichannel notch-filtered INFINITY spectrograph (Jobin-Yvon-Horiba SAS, Longjumeau, France) equipped with a Peltier cooled CCD matrix and a "XY" spectrograph (Dilor, Lille, France) equipped with a double monochromator filter and a back-illuminated, liquid nitrogen-cooled, 2000 x 256 pixels CCD detector (Spex, Jobin-Yvon-Horiba Company) were used to record Raman spectra between 10 (XY instrument)/110 (INFINITY instrument) and $1800 \mathrm{~cm}^{-1}$, using 514.5, 532 and $647.1 \mathrm{~nm}$ exciting lines $\left(\mathrm{Ar}^{+}-\mathrm{Kr}^{+}, \mathrm{YAG}\right.$, and He-Ne lasers). The power of illumination ranged between 0.3-5 mW (INFINITY instrument, red samples) and 2-10 mW (XY instrument, colourless samples) as a function of the sample colour, instrument, and wavelength. Backscattering illumination and collection of the scattered light were made through an Olympus confocal microscope (ultra long focus Olympus x50 or x100 objectives, total magnification x500 or x1000). Digital camera coupled to the microscope was used to record optical images.

Characteristic Raman signatures of the different phases were searched for in various positions on the samples. Although most of the body signatures have only been recorded at 
the laboratory (a good view of the body microstructure is required to select grains of the different phases), the glaze and pigment signatures were easily obtained with the on-site instrument.

\section{Peak fitting and data processing}

In undertaking a curve fit of the Raman spectra, a linear baseline was first subtracted using LabSpec ${ }^{\circledR}$ software as previously discussed [5, 11-13]. We selected a 4-segment baseline: $~ 150-700,700-890,890-1300$ and $1300-1700 \mathrm{~cm}^{-1}$ for a reproducible separation of the different components of the Raman signatures. The same spectral windows were used for the extraction of the components using the Origin ${ }^{\circledR}$ software peak-fitting module (Microcal Software, Inc.).

The $\mathrm{SiO}_{4}$ tetrahedron, the building block of all silicates, amorphous or crystalline, is a very covalent entity and thus has a well-defined vibrational signature, especially in Raman scattering. Pure amorphous silica can be described as a 3D network of $\mathrm{SiO}_{4}$ tetrahedra sharing their oxygen atoms and forming Si-O-Si bridges. Consequently the density of Si-O bonds is at its maximum and melting (i.e. the softening of the 3D connected Si-O network) requires high temperatures $\left(\sim 1750^{\circ} \mathrm{C}\right)$. All applications in the science, art and technology of silicate-based ceramics and glazes consist out of a controlled modification of the 3D Si-O network by replacement of $\mathrm{Si}^{4+}$ covalent bonded atoms by non-covalent bonded atoms, hence decreasing the number of Si-O bridges and the connectivity of the network. Consequently, the melting temperature (and the viscosity at a given temperature) decreases. Other physical/chemical properties related to the density and network connectivity (thermal expansion, ion diffusion, reactivity, etc.) are modified accordingly. Because strong covalent bonded structures have Raman signatures orders of magnitude larger than those of ionic ones, the Raman spectrum of a silicate consists, as a first approximation, solely out of the signature of the Si-O network (Si$\mathrm{O}$ stretching, bending and librational/collective modes) $[2,11,12]$. Because a $\mathrm{SiO}_{4}$ tetrahedron is a solid chemical and vibrational entity (even molten silicates retain a strong polymeric character), it is well established (see references in [11,12]) that the different tetrahedral arrangements: isolated tetrahedron also called $\mathrm{Q}_{0}$, tetrahedra linked by a common oxygen atom $\left(\mathrm{Si}_{2} \mathrm{O}_{7}\right.$ or $\left.\mathrm{Q}_{1}\right)$, tetrahedra linked by sharing 2 oxygen atoms (three $\left(\mathrm{Si}_{3} \mathrm{O}_{9}\right)$ and $\mathrm{n}$ tetrahedral-cycles: $\mathrm{Q}_{2}$ ), by sharing 3 oxygen atoms (e.g. in some chains, ribbons and layers) and $\mathrm{Q}_{4}$ (as in pure $\mathrm{SiO}_{2}$ )) have characteristic Raman signatures. The integral area, the bandwidth and the centre of gravity were calculated for each component using the $\mathrm{Q}_{\mathrm{n}}$ model. This model allows for a comparison of the glassy silicate nanostructure over a large composition range. A Gaussian shape was chosen for all Raman lines assigned to glassy silicates because of the amorphous state of the examined materials. A Lorentzian shape was used for crystalline phase components, for instance, pigments, crystalline precipitates or unreacted pristine quartz.

\section{RESULTS}

\section{Characteristic Raman signatures}

Figure 1 shows examples of characteristic Raman signatures recorded on site on the colourless glaze of the green bowl with the $27^{\text {th }}$ August 1726 date (Plate $1 \mathrm{~b} \& \mathrm{~h}$ ). The signature of an alumina and silica-rich glassy phase with a characteristic strong band at $\sim 490$ $\mathrm{cm}^{-1}$ (Si-O bending mode) and a smaller band at $\sim 1000 \mathrm{~cm}^{-1}$ (Si-O stretching mode), typical of a high-temperature fired porcelain glaze, is obvious [5,11-13]. The fluorescence background is small because of the high quality of the material (a low porosity) [13] and can be removed very easily by subtracting a 4-segment baseline. Figure 2 shows characteristic Raman signatures recorded along the interface between the colourless glaze and the body at the fracture of the ewer stopper (ca. 1725, Plate 1g). Very similar Raman signatures were 
obtained on the Sake bottle (Plate 1e \& e'). A mullite Raman signature, with a characteristic broad doublet at $\sim 305-410 \mathrm{~cm}^{-1}$ and narrow peaks at 960 and $1160 \mathrm{~cm}^{-1}[9,14,15]$, is observed on unglazed body regions and/or on fractures. The narrow peak at $480 \mathrm{~cm}^{-1}$ could correspond to a natural mullite polymorph, disthene [16]. The $1350-1600 \mathrm{~cm}^{-1}$ doublet indicates that carbon traces are present, which is in accordance to sintering under strong reducing conditions. A rather surprising signature of lapis lazuli (Fig. 2) is observed in some places (dark grains of the Fig. 3b micrograph): assignment is easy with the very characteristic multiple resonance bands of lazurite, the coloured mineral in lapis lazuli rock : $(545 \times 2=$ $\left.1090 \mathrm{~cm}^{-1}\right)$ or combination $\left(255+545=800 \mathrm{~cm}^{-1}\right)$ of $\mathrm{S}_{3}^{-}$(255 and 285 (bending), 545 (stretching mode)) and $\mathrm{S}_{2}^{-}$(585 $\mathrm{cm}^{-1}$ shoulder) ions [17]. The limit of thermal stability of lazurite being close to $1200^{\circ} \mathrm{C}$, this temperature can be considered as the upper limit of the glaze firing temperature.

Figure 4 shows representative signatures recorded on the glossy surface and rough bottom rim of a red stoneware cup (Plate $1 \mathrm{f} \& \mathrm{f}^{\prime}$ ). No signature of glaze was detected, according to a polished artefact. Optical micrographs (Fig. 5) show a complex microstructure made of large grains (appearing black at x100 magnification and white at x800 magnification), very small ones at the grain boundary and of "homogenous" large grains. Such dispersion of fine-grained particles at the grain boundary indicates a sintering with a low viscosity liquid phase (consistent with a calcium-rich flux) or a precipitation from the intergranular liquid phase. The high quality of the polishing (Plate $1 \mathrm{f} \mathrm{\&} \mathrm{f')} \mathrm{facilitates} \mathrm{the}$ microstructure observation and the recording of spectra. Hematite $\left(\alpha-\mathrm{Fe}_{2} \mathrm{O}_{3}\right)$ signatures $[16,18]$ dominate the spectra, in all the regions, except for large "white" grains: it is clear that these large grains are pure $\alpha$-quartz (sand grain) with a more or less dissolved smoothed contour according a very reactive Ca-rich flux. The rather intense Raman band at $670 \mathrm{~cm}^{-1}$ is consistent with a partial reduction of $\alpha-\mathrm{Fe}_{2} \mathrm{O}_{3}$ to $\mathrm{Fe}_{3} \mathrm{O}_{4}$ under strong reducing condition [19].

The availability of a broken flat stopper (Plate $1 \mathrm{~d} \& \mathrm{~d}$ ') makes it possible to do a comprehensive study of the different phases of the body (Fig. 6). Blue underglaze decoration technique was studied from the beginning of Meissen porcelain production using cobalt ores from the Ertzgebirge Mountains. The first success in this regard is attributed to David Köhler in 1719 [7,8]and this date can be considered as ante quem for our sample. Quartz signatures are rare. The mullite signature is obvious in many places. Other frequent signatures are : i) calcite (lime) with characteristic narrow peak at $480 \mathrm{~cm}^{-1}$ (disthene ?, [16]), $1085 \mathrm{~cm}^{-1}$ [16], ii) $\mathrm{Ca}_{3}\left(\mathrm{Si}_{3} \mathrm{O}_{9}\right), \alpha$-wollastonite, a calcium silicate, with characteristic narrow peaks at $450-460$ and $985 \mathrm{~cm}^{-1}[2,16]$, iii) anatase a $\mathrm{TiO}_{2}$ polymorph with a very strong peak at $145 \mathrm{~cm}^{-1}$ [15,16]. Unassigned narrow peaks at 1005 (Zircon ?), 1010 (gypsum?) and 1045 (?) $\mathrm{cm}^{-1}$ are also observed. Very similar signatures are observed on the fractured ewer stopper rim (MNC7152) and on the coffee cup (MNC14231). It is obvious that calcium-rich raw materials have been used. The main albaster peak is occurs at $\sim 1010 \mathrm{~cm}^{-1}$, which is consistent with the observed signature in Fig. 6, but the decomposition of this material is expected to be complete in a porcelain body fired above $1200-1300^{\circ} \mathrm{C}$.

Raman signatures recorded on the figurine glaze (Plate 1c, MNC 11056) show very different features. Figure 7 compares the Raman signatures of the glaze recorded above the Meissen signature on the bowl bottom (MNC 2274 ) and on the blue lozenges of the Harlequin costume (MNC 11056) : the MNC $2274^{9}$ glaze signature shows a strong Si-O bending band and a rather small Si-O stretching, as expected for a high-temperature fired, silica- and alumina-rich glaze $[2,9,11,12]$. On the other hand the intensity of the two bands is rather similar for the figurine glaze (MNC 11056). Furthermore the Si-O stretching envelope peaks at $\sim 1000 \mathrm{~cm}^{-1}$ instead of $\sim 1125 \mathrm{~cm}^{-1}$. Both the two latter characteristics indicate a lowtemperature fired, lead-based glaze $[2,9,11]$. The centre of gravity of the different $Q_{n}$ 
components are given in Table I. Characteristic wavenumber and area ratios have been calculated. Note the very different values of the polymerisation index (Ip), 3.5 and 1-1.5, values consistent with high and low temperature of firing, respectively.

Spectra of yellow, maroon and green glazes (Fig. 8) show the signature of Naples yellow (512 narrow peak, the stronger ca. $135-140 \mathrm{~cm}^{-1}$ peak is out of the range of the portable instrument), a typical lead-based pigment $[9,11,20]$, confirming the use of lead-based glazes for the figure decor, as in soft-paste porcelain technology [2,3].

The small small $635 \mathrm{~cm}^{-1}$ peak on the green glaze signature (Fig. 8, MNC 2274) shows that cassiterite $\left(\mathrm{SnO}_{2}\right)$ has been added to achieve the "vert d'eau" pale colour. No other pigment signature was observed, the use of $\mathrm{Cu}^{2+}$ ion is likely (the characteristic alternative $\mathrm{Cr}$ $\mathrm{O}$ bond signature at $\sim 830 \mathrm{~cm}^{-1}[9,21]$ is not observed). This is very different from the technique used to colour the Harlequin costume lozenges and leafs (Plate 1c, Fig. 8), where green colour is achieved using a mixture of blue and Naples yellow pigments. Note cassiterite is also observed in the blue flower décor.

\section{DISCUSSION}

This preliminary investigation of a limited selection of Meissen artefacts has led to some interesting results: specific stoneware microstructures with rather large quartz grains and a very homogeneous distribution of haematite grains has been documented. This microstructure is consistent with the use of specific iron-containing clays like Zwickau clay, Okrilla kaolin or Nurnberg bole. The study of stoneware series is required to establish the criteria to discriminate between original Meissen artefacts and fakes. We expect that a combination of microstructure criteria and Raman signature parameters will be efficient.

On the basis of our experience in Raman studies of porcelain, the most important characteristic of early Meissen production is the nearly pure mullite Raman signature obtained for the body. More analyses are needed to establish a definitive conclusion, but the additional calcite and $\alpha$-wollastonite Raman signatures appear to be very specific of items of the earliest period of production. The anatase signature is observed as in many Vietnamese and Chinese productions and is therefore only a criterion of a secondary nature, $\mathrm{TiO}_{2}$ polymorph traces being common in many kaolin. The shape of the glaze Raman signatures (intensity of the $\sim 585 \mathrm{~cm}^{-1}$ shoulder, relative intensity of the Si-O stretching components, intensity of the $\sim 485$ $\mathrm{cm}^{-1}$ peak, ...) vary between artefacts. More work on more pieces is needed to say if these changes are characteristic of different compositions. Note we do not have evidence of unreacted feldspar grains in the studied pieces as observed in many other hard-paste porcelains $[5,9]$. The lack of any significant quartz signatures in the (white) porcelain paste confirms that different recipes and raw materials have been used to prepare stoneware and porcelain pastes according to historical records [7]. The very high intensity of haematite and quartz Raman signatures makes it difficult to observe a mullite spectrum (the large ionicity of mullite structure lead to a weak Raman signature) in red stoneware using portable instruments without any microscope accessory.

The calcite Raman signature is consistent with the expected Böttger compositions (Cabased porcelain before 1725, feldspar addition only being made after 1730 [4,6-8]). The persistence of the calcite signature in high-temperature fired samples indicates that large quantities and/or coarse grains have been used (according to the $6 \% \mathrm{wt} \mathrm{CaO}$ value given for 1712 body and glaze compositions after Kingery [4]). However, complete decomposition and reaction of calcium carbonate are rather slow in reducing atmosphere and require good grinding technology and/or firing temperatures above $1300^{\circ} \mathrm{C}$. The Raman signature of $\alpha-$ wollastonite and the needle form of the mullite grains (Fig. 5) confirm the high-temperature firing [22,23]. The numerous bubbles observed in the colourless glaze (Fig. 3a) are consistent with the numerous calcite grains in the body. The presence of a dispersion of lapis lazuli 
grains at the glaze-body interface of the white ewer stopper was unexpected. The very particular Raman signature of this ultramarine aluminosilicate makes the assignment unambiguous. Formation of synthetic ultramarine silicate is unlikely. It is well known that traces of blue pigment enhance the quality of the "white" colour. This goal is generally achieved by the addition of a small amount of cobalt (from cobalt ore or cobalt-containing glass ("smalt")). Lazurite grains give a upper limit of $\sim 1200^{\circ} \mathrm{C}$ for the glaze firing temperature. This result implies that the glaze was deposited on already high-temperature fired porcelain body. Most of the red stoneware and white porcelain artefacts of the Böttger production have been designed with the help of Johann Jacob Irminger, a Jewellery master, educated in the preparation of fine stones such as lapis lazuli. The Raman signature of lapis lazuli indicates that technology exchanges between jewellery art and glaze preparation have been made at the Böttger' factory.

\section{CONCLUSION}

These preliminary results demonstrate that useful conclusions can be drawn from on site experiments. However, the spectrum quality and precision of the analyzed zone, to date, are not as good as those achieved in the laboratory with a large palette of instruments (high resolution or high sensitivity instruments, microscopes equipped with cameras, ...). For instance we were unable to analyze the Raman signatures of all the phases of the stoneware and porcelain bodies (some of them have a very weak Raman signature), which is almost possible at the laboratory. The comparison of the microstructure micrographs with the Raman signature of the different phases will be very efficient to discriminate between fakes and original Meissen items. However this requires broken body section of porcelain items and the use of a Raman spectrometer equipped with a microscope (laboratory instrument). The original polishing of stoneware makes this examination very easy.

\section{ACKNOWLEGMENTS}

The authors thank the Museum Director, Mrs Antoinette Hallé for her help and support. Special thanks to Drs J. Oswalt and L. Le Bihan, Jobin-Yvon SAS, Longjumeau, providing their portable spectrometers. Laurianne Combes is acknowledged for her contribution in the data fitting and Dr Linda Prinsloo, University of Pretoria for her critical reading of the manuscript..

\section{REFERENCES}

1. Colomban Ph, Milande V, Lucas H, J. Raman Spectr. 2004; 35: 68.

2. Colomban $\mathrm{Ph}$, Glasses, Glazes and Ceramics - Recognition of the Ancient Technology from the Raman Spectra, chapter in Raman Spectroscopy in Archaeology and Art History, Edwards HGM and Chalmers JM (Eds), Royal Society of Chemistry, London, 2005, pp

3. Colomban Ph., Robert I., Roche C., Sagon G., Milande V., Revue d’Archéométrie 2004; 28:153.

4. Kingery W.D., The Development of European porcelain, in Technology and Style, Ceramic and Civilization vol III, W.D. Kingery Ed., The American Ceramic society, Westerville, 1986, pp153-180.

5. Colomban Ph, Treppoz F. J. Raman Spectr. 2001; 32: 93.

6. A. d'Albis, The History of Innovation in European porcelain Manufacture and the Evolution of Style: Are they related?, in Technology and Style, Ceramic and Civilization vol II, W.D. Kingery Ed., The American Ceramic Society, Columbus, 1986, pp397-412. 
7. W. Goder et al., Meissen, La découverte de la porcelaine européenne en Saxe - J.F. Böttger, 1709-1736, Pygmalion-Gérard Watelet, 1984.

8. M. von Hornig-Sutter, Meissener Porzellane des 18. Jahrhunderts in Visier von Kunstgeschichte und Naturwissenschaft, Weltkunst (Heft 2), 1985; 110.

9. Colomban Ph, Sagon G, Faurel X. J. Raman Spectr. 2001; 32: 351.

10. Exhibition Catalogue, "Porcelaine de Saxe », Musée national de Céramique, JulyOctober 1952, Sèvres, 1952.

11. Colomban Ph. J. Non-Crystalline Solids, 2003; 322: 180.

12. Colomban Ph., Paulsen O., J. Amer. Ceram. Soc. 2005; 88: 390.

13. Colomban Ph, Mater. Res. Soc. Symp. Proc. 2005; 852E: OO8.4.1.

14. Michel D., Colomban Ph., Abdhassani S., Voyron F., Kahn-Harari A., J. Eur. Ceram. Soc. 1996; 16: 161.

15. Liem NQ, Sagon G, Quang VX, Tan HV, Colomban Ph. J. Raman Spectr. 2000; 31: 933.

16. Griffith WP, ch 12. in "Infrared and Raman Spectroscopy of Lunar and Terrestrial Minerals”, Ed. Karr C Jr, Academic Press: New York, 1975.

17. Colomban Ph., J. Raman Spectrosc. 2003; 34: 420.

18. Neff D., Reguer S., Bellot-Gurlet L., Dillmann Ph., Bertholon R., J. Raman Spectrosc. 2004; 35: 739.

19. Colomban Ph., Sagon G., Huy L.Q., Liem L., Mazerolles L., Archeometry 2004; 46: 125.

20. Sakellariou K., Miliani C., Morresi A., Ombelli M., J. Raman Spectrosc. 2004; 35: 61.

21. Ph. Colomban, R. de Laveaucoupet and V. Milande, J. Raman Spectr. 36, (2005).

22. Carty W.M., Serrapali U., J. Amer. Ceram. Soc. 1998; 81: 3.

23. Jouenne C.A., Céramique Générale, Gauthier-Villars, Paris, 1959. 
Table 1 : Characteristics of the Raman signature of representative Meissen glazes.

\begin{tabular}{lllllllllll}
\hline $\mathrm{MNC}$ & glaze & $v \mathrm{Q}_{0}$ & $v \mathrm{Q}_{1}$ & $v \mathrm{Q}_{2}$ & $v \mathrm{Q}_{3}-\mathrm{Q}_{4}$ & $v \mathrm{Q}_{2} / v \mathrm{Q}_{1}$ & $v \mathrm{Q}_{3} / v \mathrm{Q}_{1}$ & $\mathrm{AQ}_{2} / \mathrm{AQ}_{1}$ & $\mathrm{AQ}_{3} / \mathrm{AQ}_{1}$ & $\mathrm{I}_{\mathrm{p}}$ \\
\hline $2274^{9}$ & $\begin{array}{l}\text { Colorless, } \\
\text { near }\end{array}$ & 794 & 937 & 1031 & 1126 & 1.1 & 1.2 & 1.7 & 3.3 & 3.5 \\
& & & & & & & & & & \\
$2274^{9}$ & $\begin{array}{l}\text { blue mark } \\
\text { green }\end{array}$ & & & & & & & & & \\
11056 & blue & & 918 & 1000 & 1131 & 1.1 & 1.2 & 4 & 0.8 & 1.4 \\
\hline
\end{tabular}

Polymerization index : Ip $=\mathrm{A}_{(500)} / \mathrm{A}_{(1000)}$ 


\section{FIGURES CAPTIONS}

\section{Plate 1}

a) view of the on-site sample examination; b) note the laser spot is visible on the reverse side through the translucent porcelain bowl; c) figurine ( $\mathrm{h}=12 \mathrm{~cm})$, MNC11056; d) flat stopper (diameter $\sim 15 \mathrm{~cm}, \mathrm{MNCxxx}$ ) and its reverse side with the cut mark, expected from after 1719 (d'); e) Irminger designed Sake bottle from 1715 (MNC451, h= $20 \mathrm{~cm}$ ) and e') note the sand on the bottom used to prevent the sticking between the piece and the support; f) red polished stoneware tea cup from ca. 1710-1715 and f') its reverse side (MNC308, diameter $=8 \mathrm{~cm}$ ); g) ewer stopper from $\sim 1725$ (MNC 7152, diameter $=7.5 \mathrm{~cm}, \mathrm{~h}=4.5 \mathrm{~cm}$ ); h) bowl made on $27^{\text {th }}$ august $1726 \mathrm{~g}$ ) and g') (MNC2274-9, diameter $=\mathrm{h}=12 \mathrm{~cm}$ ); a "celadon" coffee cup f) \& f') (MNC14231, diameter $=6.5 \mathrm{~cm}, \mathrm{~h}=5.5 \mathrm{~cm})$. Photograph, Ph. Colomban.

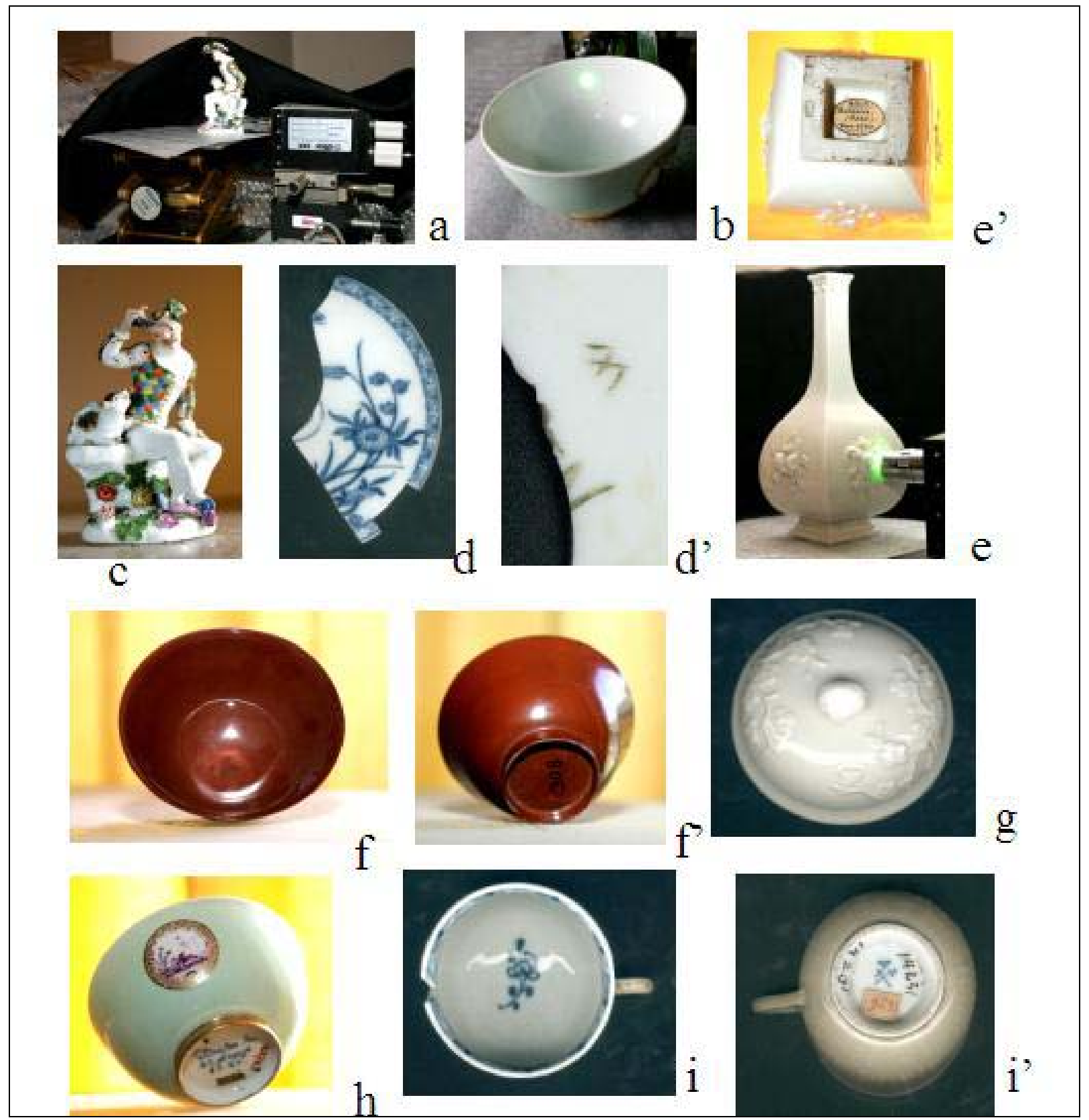



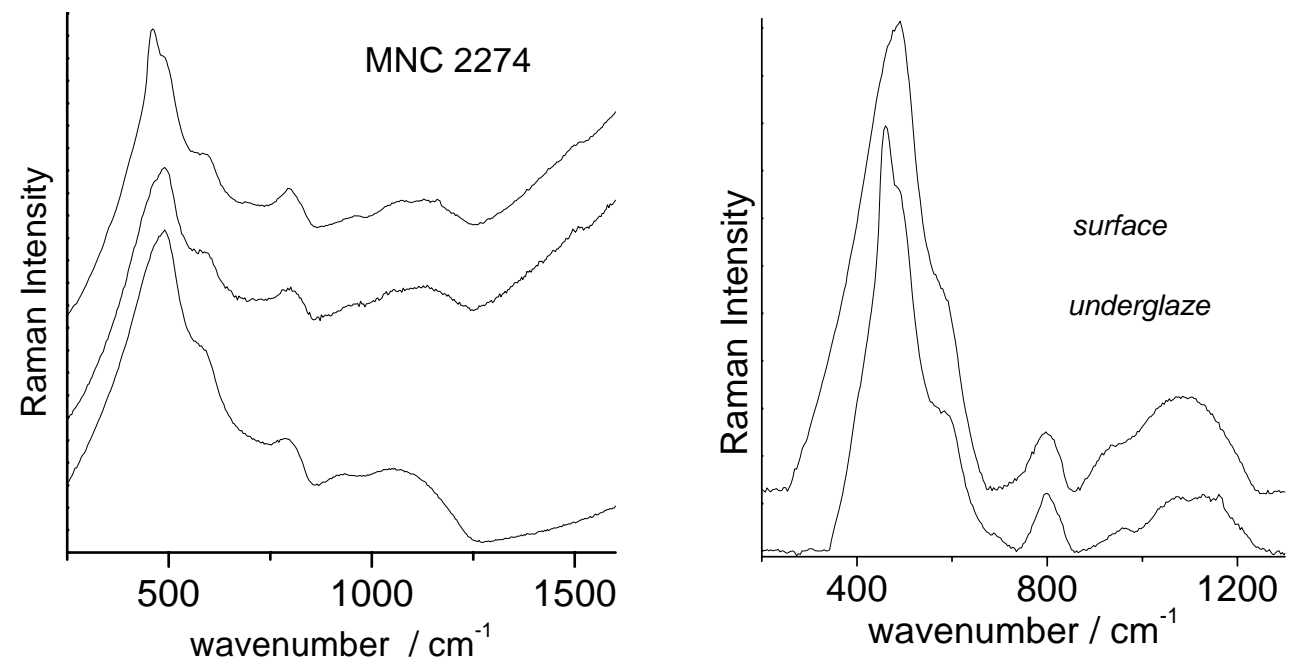

Figure 1 : Examples of "raw" spectra on-site recorded on different positions on the green bowl glaze (MNC2274) ; spectra obtained after baseline subtraction are shown; $\alpha$-quartz narrow components at $\sim 465$ and $1150 \mathrm{~cm}^{-1}$ are visible in the spectra recorded at the glazebody interface.

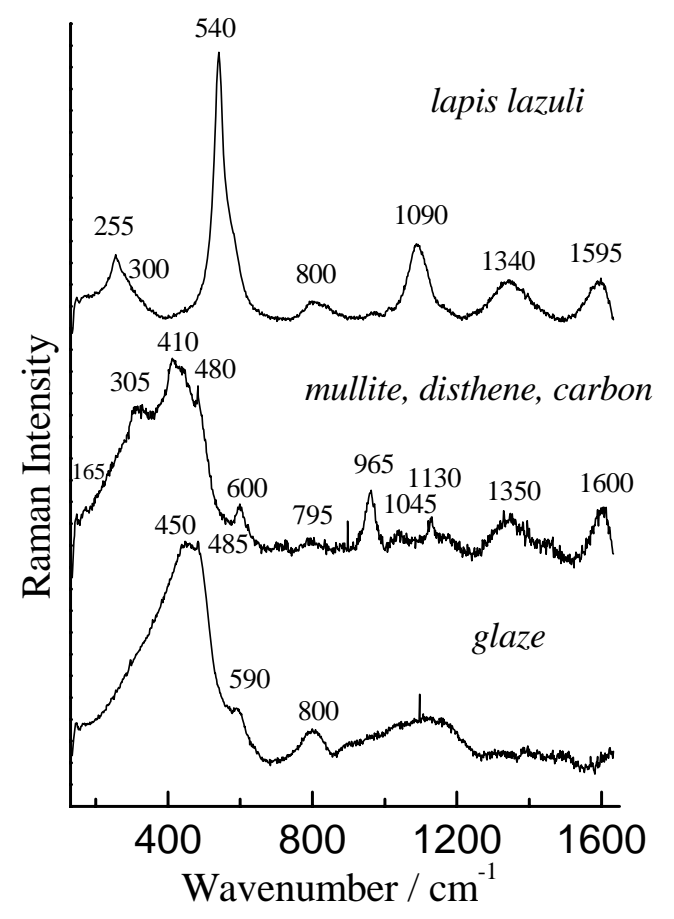

Figure 2 : Representative Raman spectra recorded at the laboratory on the glaze-body interface fracture of the ewer stopper from 1725 (MNC 7152); note the lapis lazuli signature. 


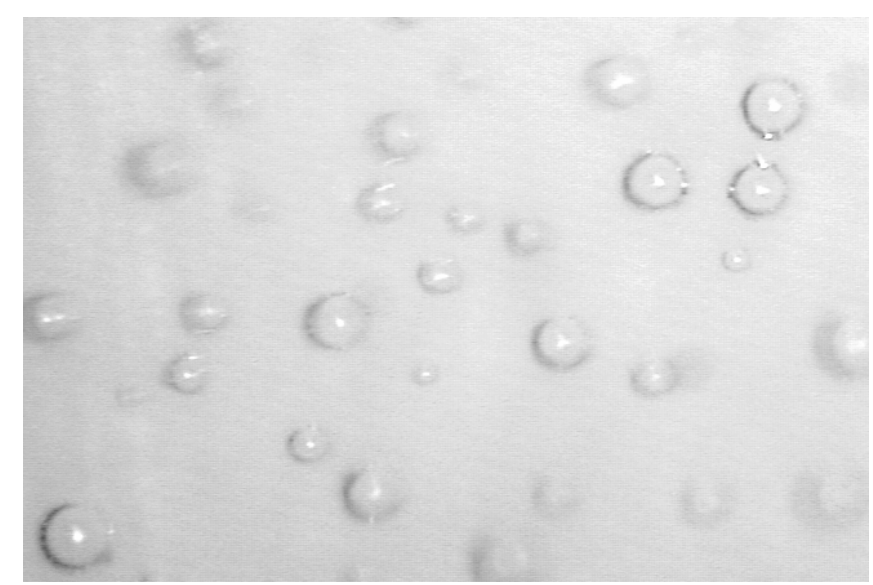

a) $==5 \mu \mathrm{m}$

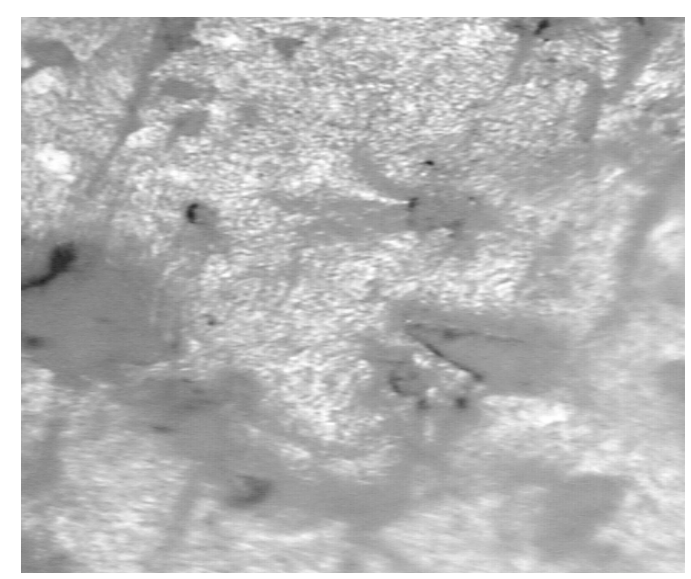

b) $==5 \mu \mathrm{m}$

Figure 3: Optical micrographs made on the fracture of the MNC7152 ewer stopper glaze (a) and body (b); note in grey the mullite needles, signature of a high-temperature liquid phase sintering, and in black the lazurite particles at the body-glaze interface.

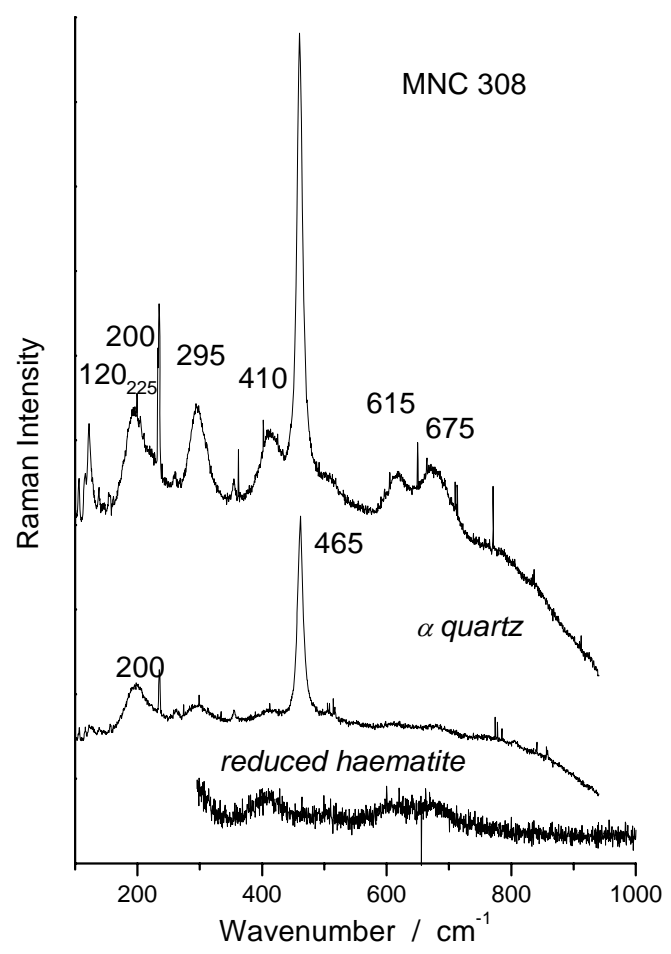

Figure 4: Representative Raman spectra recorded at the laboratory on red stoneware (MNC 308): main signature and specific signature of $\alpha$-quartz and reduced haematite. 


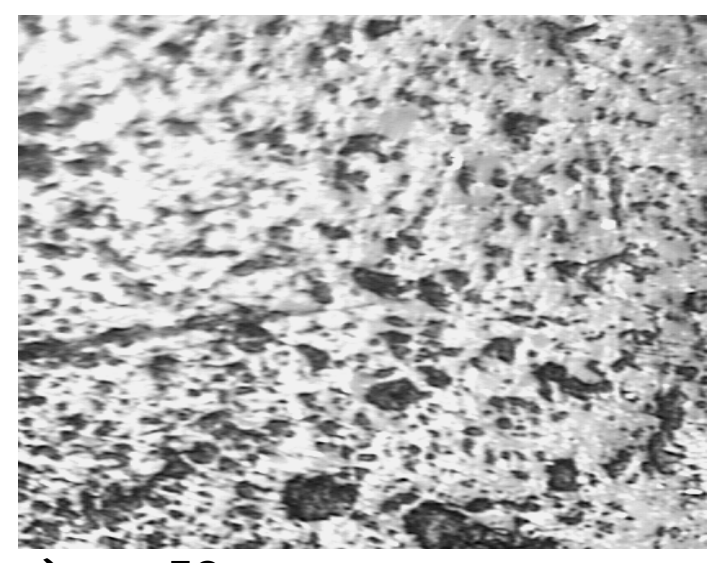

a) $==50 \mu \mathrm{m}$

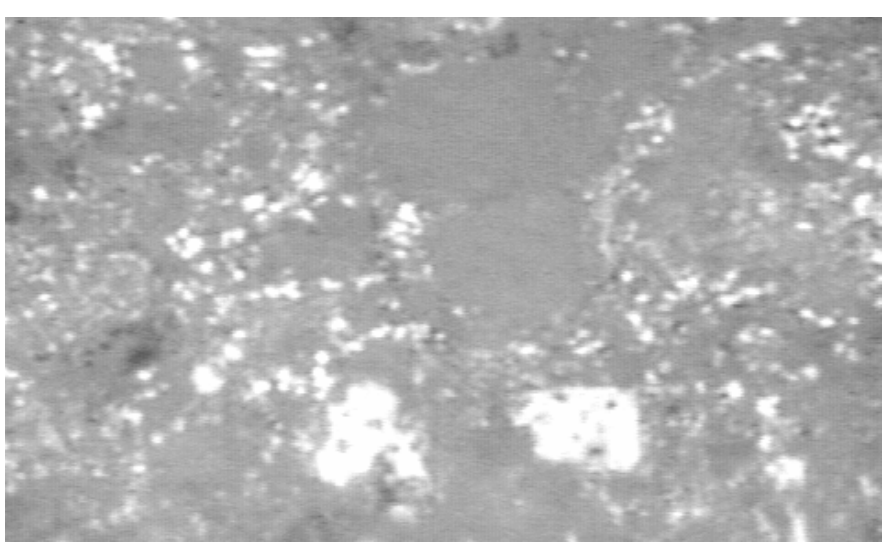

b) $==5 \mu \mathrm{m}$

Figure 5: Typical optical micrographs of red polished stoneware body (a, b, MNC308), ewer stopper body (b) and glaze (b', MNC2274). Note the of the large quartz grain, with concave interface indicating a dissolution by a very active liquid flux.
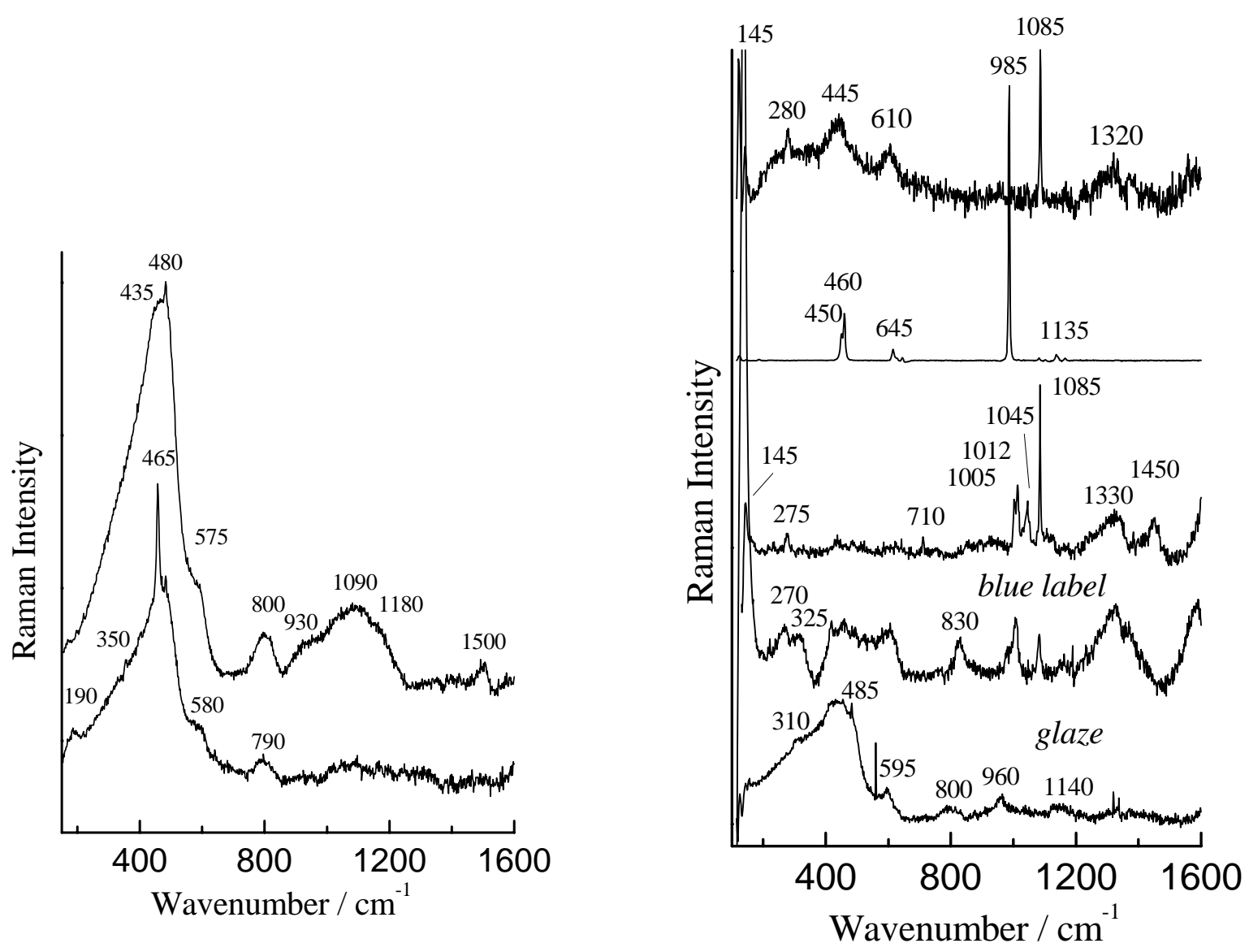

Figure 6 : Representative Raman signatures recorded at the laboratory on the fracture of the flat blue underglaze decorated broken stopper; see text for the phase assignment. Baselines have been subtracted. 


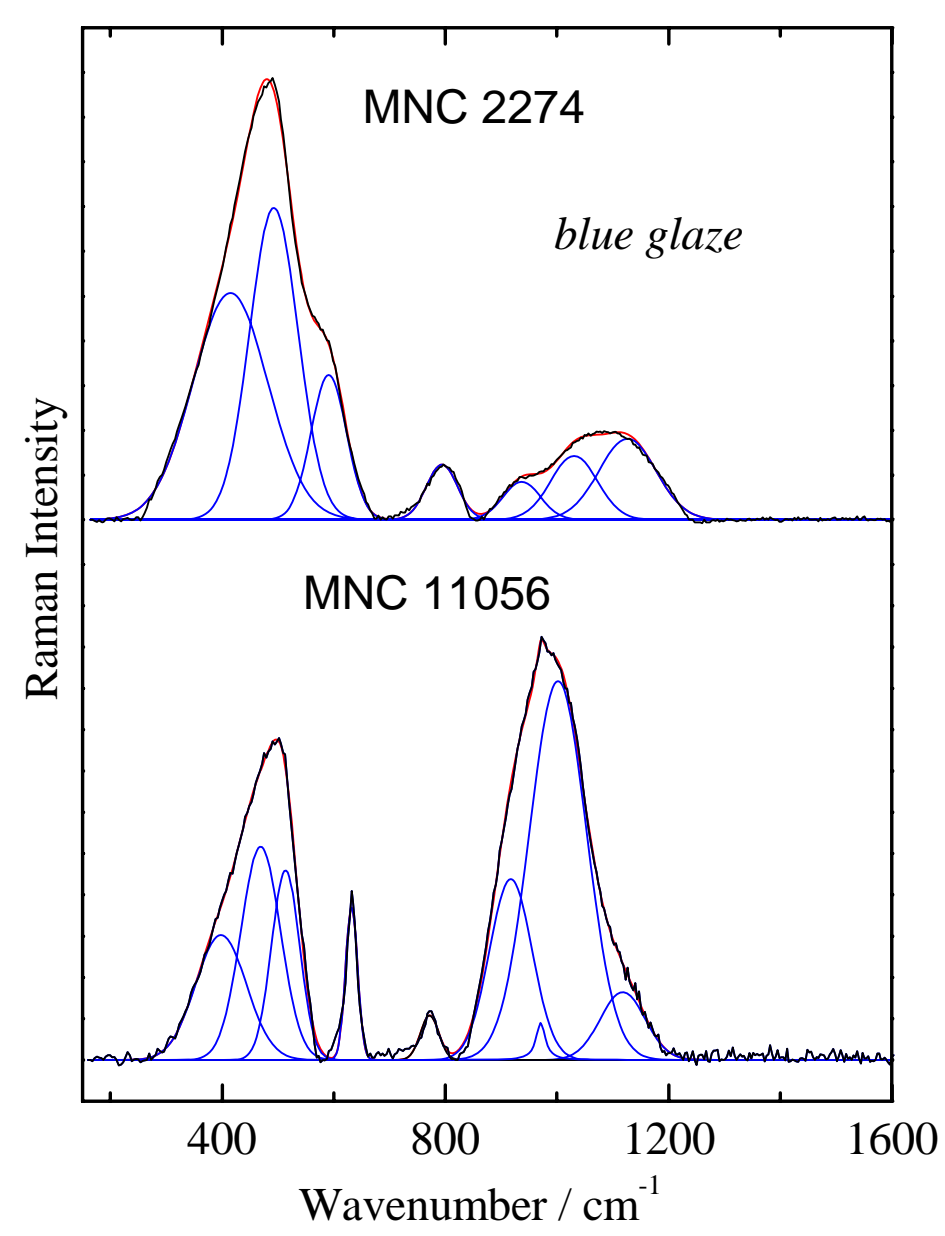

Figure 7 : Comparison between on-site recorded glaze spectra for MNC2274 ${ }^{9}$ bowl and 11056 figure ; spectra have been recorded in the vicinity of the blue signature (bowl bottom and on a blue lozenge of the Harlequin costume (after baseline subtraction and peak fitting). 

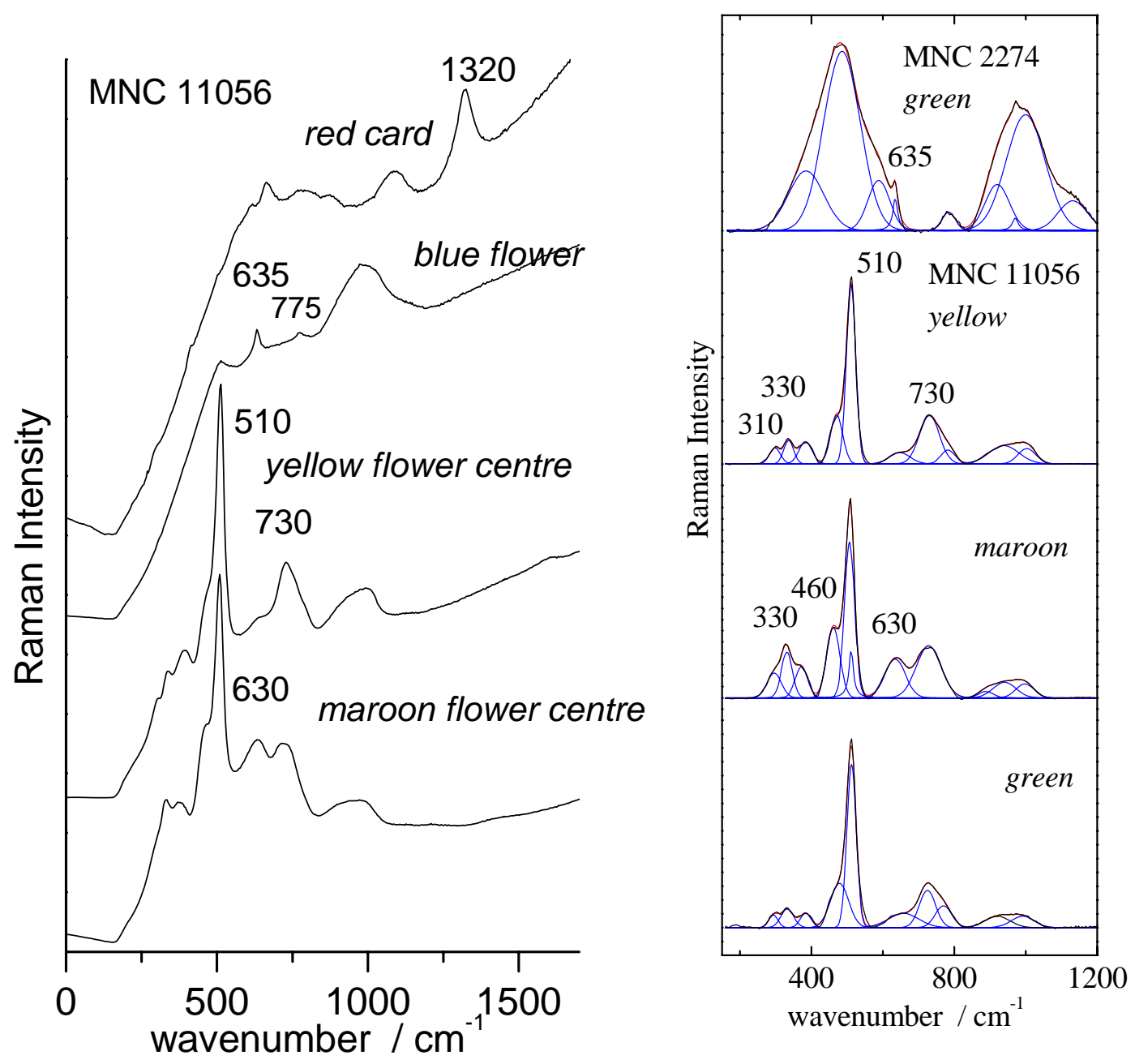

Figure 8 : Examples of "raw" spectra on-site recorded on different places of the figurine glaze (MNC2274); corresponding spectra obtained after baseline subtraction and component peak fitting are given. 